Samuel Murray: He was one of Eakins's most talented students and shared a studio with him in Philadelphia. A sculptor who accompanied Eakins on trips to WW's Camden home, he later accompanied the New York sculptor William O'Donovan to WW's home when O'Donovan was working on a bust of WW. Murray's photographs of WW may well have been used to aid O'Donovan in his work.

The University of Iowa

Ed Folsom

\title{
BIBLIOGRAPHIC NOTE
}

The information for these notes has come from many sources. The best essay on Whitman and photography is Gay Wilson Allen, "The Iconography of Walt Whitman," in Edwin Haviland Miller, ed., The Artistic Legacy of Walt Whitman (New York: New York University Press, 1970), 127-152. Earlier studies that are still useful include Richard Maurice Bucke, "Portraits of Walt Whitman," New England Magazine, 20 (March 1899), 33-50; Sadakichi Hartmann, A Note on the Portraits of Walt Whitman (New York: Sparrow, 1921); and Jeanette Gilder's recollections of WW's sittings for Cox and Gutekunst in The Critic, n.s. 7 (23 April 1887), 207-208; and n.s. 12 (12 October 1889), 179. Basic histories of nineteenth-century American photography include Robert Taft, Photography and the American Scene: A Social History, 1839-1889 (New York: Macmillan, 1939); Beaumont Newhall, The Daguerreotype in America (New York: Dover, 1976); Beaumont Newhall, The History of Photography from 1839 to the Present Day (New York: Museum of Modern Art, 1949, rev. 1964); William Welling, Photography in America: The Formative Years 18391900 (New York: Thomas Y. Crowell, 1978); Peter Pollack, The Picture History of Photography (New York: Harry N. Abrams, 1969); and George Gilbert, Photography: The Early Years (New York: Harper and Row, 1980) [a good book with some awful mistakes, including one Whitman photo misidentified as Longfellow!]. Information on Brady and Gardner is available in James D. Horan, Mathew Brady: Historian with a Camera (New York: Bonanza, 1955), and Josephine Cobb, Mathew B. Brady's Photographic Gallery in Washington (Washington, D.C.: Columbia Historical Society Records, vols. 53-56). Useful information on Cox is in Marchal E. Landgren, "George C. Cox: Whitman's Photographer," Walt Whitman Review, 9 (March 1963), 11-15. On Whitman and Eakins, see Gordon Hendricks, The Photographs of Thomas Eakins (New York: Grossman, 1972), esp. 9-10; 109-114; Lloyd Goodrich, Thomas Eakins: His Life and Work (New York: Whitney Museum, 1933), 121-124; and William Innes Homer, "Who Took Eakins' Photographs?" ARTnews (May 1983), 112-119. General information about early Philadelphia photography can be found in Kenneth Finkel, Nineteenth-Century Photography in Philadelphia (New York: Dover, 1980). William White's back-cover comments in the Walt Whitman Review over the years concerning specific photographs have been helpful.

Whitman's comments on photographs and photographers can be found scattered in all six volumes of Horace Traubel, With Walt Whitman in Camden (1905-1982); in J. Johnston and J. W. Wallace, Visits to Walt Whitman in 1890-1891 (London: George Allen \& Unwin, 1917); in William Sloane Kennedy, Reminiscences of Walt Whitman (London: Alexander Gardner, 1896); in Whitman's newspaper pieces in Cleveland Rodgers and John Black, eds. The Gathering of Forces, 2 vols. (New York: 
G. P. Putnam's Sons, 1920); in Whitman's various notebooks in Edward Grier, ed., Notebooks and Unpublished Prose Manuscripts, 6 vols. (New York: New York University Press, 1984), and in William White, ed., Daybooks and Notebooks, 3 vols. (New York: New York University Press, 1978); and in Whitman's letters in Edwin Haviland Miller, The Correspondence, 6 vols. (New York: New York University Press, 1961-1977). See also Thomas L. Brasher, Whitman as Editor of The Brooklyn Daily Eagle (Detroit: Wayne State University Press, 1970)); and Joseph Jay Rubin, The Historic Whitman (University Park: Pennsylvania State University Press, 1973), for WW's comments on early photographers and studios.

Of course the most complete inventory of Whitman photographs is Henry S. Saunders's Whitman Portraits (privately made, Toronto, 1922). 